JKKP : Jurnal Kesejahteraan Keluarga dan Pendidikan

http://doi.org/10.21009/JKKP

DOI: doi.org/10.21009/JKKP.061.04

E-ISSN : 2597-4521

\title{
PENGARUH PENGETAHUAN IBU TENTANG MANAJEMEN LAKTASI TERHADAP PERILAKU PEMBERIAN ASI EKSKLUSIF
}

\author{
Cindy Aulia Risadi ${ }^{1, a)}$, Nurlaila A. Mashabi ${ }^{1, b)}$, Prastiti Laras Nugraheni ${ }^{1, c)}$ \\ Email: ${ }^{\text {a) }}$ risadicindy@gmail.com, ${ }^{\text {b) }}$ Laila.mashabi@yahoo.com,, prastitilaras.nugraheni@yahoo.co.id \\ ${ }^{1}$ Pendidikan Kesejahteraan Keluarga, Fakultas Teknik, Universitas Negeri Jakarta, \\ Jl. Rawamangun Muka, Jakarta 13220 Telepon: (021) 47864808 Fax: 47864808
}

\begin{abstract}
Abstrak
Indonesia saat ini masih menghadapi masalah gizi ganda, yaitu kondisi dimana di satu wilayah masih banyaknya jumlah penderita gizi kurang, sementara di wilayah lain jumlah masyarakat yang mengalami gizi lebih cenderung meningkat. Masalah gizi ganda ini sangat erat kaitannya dengan gaya hidup masyarakat dan perilaku gizi. Salah satu faktor yang mempengaruhi stunting (masalah kurang gizi) pada Baduta (Bayi Dua Tahun) ialah ASI tidak diberikan secara eksklusif selama 6 bulan pertama. Ibu tidak memberikan ASI eksklusif disebabkan oleh beberapa alasan, antara lain pengetahuan ibu tentang manajemen laktasi masih rendah. Penelitian ini bertujuan untuk mengetahui pengaruh pengetahuan manajemen laktasi terhadap perilaku pemberian ASI eksklusif. Jenis penelitian ini adalah kuantitatif dengan metode survey yang dilakukan pada ibu yang memiliki anak usia 0-6 bulan di 6 Posyandu Kelurahan Jati, Jakarta Timur. Sampel yang digunakan dalam penelitian ini sebanyak 57 responden. Teknik sampling yang digunakan adalah simple random sampling. Hasil dari penelitian ini menunjukkan bahwa terdapat pengaruh antara pengetahuan manajemen laktasi terhadap perilaku pemberian ASI eksklusif pada ibu dengan nilai signifikansi regresi sebesar 35,58 dengan koefisien korelasi sebesar $(0,627)$ dan pengaruh sebesar $39,28 \%$ terhadap perilaku pemberian ASI eksklusif.
\end{abstract}

Kata Kunci: ASI Eksklusif, manajemen laktasi, pengetahuan

The Influence of Lactation Management Knowledge on Exclusive Breastfeeding Behavior

\begin{abstract}
Indonesia is currently still facing multiple nutritional problems, namely conditions where in one region there are still a large number of malnourished people, while in other regions the number of people who experience nutrition is more likely to increase. This dual nutrition problem is very closely related to people's lifestyle and nutritional behavior. One of the factors that affect stunting (problem of malnutrition) in Baduta (Two-Year Baby) is that breast milk is not given exclusively for the first 6 months. Mothers not giving exclusive breastfeeding are caused by several reasons, including mother's knowledge about lactation management. This research aimed to determine the influence of lactation management knowledge on exclusive breastfeeding. The research was categorized into quantitative research with survey method on mothers who have children age 0-6 months at 6 integrated health service posts (Posyandu in Bahasa Indonesia) in Jati, East Jakarta. The amount of samples used in this research was 57 respondents. Sampling method used in this study was simple random sampling. The results showed that there were influences on lactation management knowledge towards exclusive
\end{abstract}


breastfeeding behavior of mothers with regression significant value of 35.58 (coefficient relation $=0.627$ ) and influence of $39.28 \%$ on exclusive breastfeeding behavior.

Keywords : exclusive breastfeeding, knowledge, lactation management

\section{PENDAHULUAN}

Indonesia saat ini masih menghadapi masalah gizi ganda, yaitu kondisi dimana di satu wilayah masih banyaknya jumlah penderita gizi kurang, sementara di wilayah lain jumlah masyarakat yang mengalami gizi lebih cenderung meningkat. Masalah gizi ganda ini sangat erat kaitannya dengan gaya hidup masyarakat dan perilaku gizi. Perilaku gizi yang benar sebaiknya dilakukan pada setiap tahap kehidupan mulai dari tahap Bayi dibawah Dua Tahun (Baduta) hingga Lansia. Salah satu faktor yang mempengaruhi stunting (masalah kurang gizi) pada Baduta (Bayi Dua Tahun) ialah ASI tidak diberikan secara eksklusif selama 6 bulan pertama (Hien Nguyen Ngoc \& Kam Sin, 2008).

Pemberian ASI eksklusif menjadi tidak efektif disebabkan oleh beberapa faktor, salah satunya ialah perilaku pemberian ASI yang kurang tepat, seperti; (1) Tidak membersihkan payudara terlebih dahulu; (2) Kepala bayi terletak di siku sehingga bayi menunduk/kepala bayi dari atas payudara; (3) Badan bayi tidak menghadap ke badan ibu; (4) Kepala bayi menoleh sehingga leher bayi berputar; (5) Badan ibu condong ke depan; (6) Hanya bahu bayi yang ditopang oleh tangan ibu; (7) Dagu bayi menempel pada payudara ibu; (8) Dada bayi tidak menempel pada dada ibu; (9) Mulut bayi tidak terbuka, bibir bayi "mecucu", areola bagian atas terlihat sedikit (Hesti, 2013).

Akibat dari pemberian ASI yang salah antara lain puting akan nyeri, ASI tidak dapat dikeluarkan dengan efektif sehingga payudara akan bengkak, suplai ASI berkurang sehingga bayi tidak puas menyusu, bayi akan frustasi, menolak menghisap hingga bayi gagal tumbuh dengan baik. Penyebab dari kesalahan pemberian ASI tersebut diantaranya karena kurangnya pengetahuan ibu. Menurut WHO/UNICEF, standar emas pemberian makan pada bayi dan anak adalah 1) mulai segera menyusui dalam 1 jam setelah lahir, 2) menyusui bayi secara eksklusif sejak lahir sampai dengan umur 6 bulan, dan 3) mulai umur 6 bulan bayi mendapat Makanan Pendamping ASI (MP-ASI) yang bergizi sesuai dengan kebutuhan tumbuh kembangnya dan 4 ) meneruskan menyusui anak sampai umur 24 bulan atau lebih.

Dampak dari perilaku yang tidak benar diantaranya bayi tidak dapat menerima makanan terbaik yaitu ASI yang tidak ada satupun yang dapat menggantikannya. Hal ini dikarenakan ASI memiliki tiga aspek kelebihan, yaitu: (1) aspek gizi, (2) aspek kekebalan, dan (3) aspek kejiwaan, berupa jalinan kasih sayang yang penting untuk perkembangan mental dan kecerdasan anak (Depkes, 2003).

ASI memiliki kelebihan pada aspek gizi dikarenakan ASI adalah sumber nutrisi yang primer bagi anak sejak lahir sampai ia mampu mencernakan asupan lain setelah usia enam bulan. Lemak, protein, karbohidrat, vitamin, mineral, enzim, dan hormone yang terdapat dalam ASI tidak dapat digantikan oleh susu buatan industri. ASI mengandung zat-zat kekebalan yang melindungi anak dari infeksi dan penyakit kronis, serta mengurangi kemungkinan menderita gangguan kesehatan di kemudian hari seperti obesitas, diabetes, dan asthma (WHO, 2014).

Aspek kekebalan pada ASI memberikan perlindungan bayi dari berbagai penyakit. Penelitian yang dilakukan oleh University of Minenesita Cancer Center 2003 yang diikuti oleh Handayani dan Suradi (2004), menyatakan bahwa resiko bayi yang mendapat ASI untuk terkena Leukimia (Kanker Darah ), turun sampai $30 \%$ bila dibandingkan dengan bayi yang tidak mendapat ASI. Penelitian lain di Filipina tahun 2002 menegaskan tentang manfaat pemberian ASI eksklusif serta dampak negatif pemberian cairan tambahan tanpa nilai gizi terhadap timbulnya penyakit diare. Seorang bayi 6 bulan yang diberi air putih, teh, atau minuman herbal lainnya beresiko terkena diare 2-3 kali lebih banyak dibanding bayi yang diberi ASI eksklusif (Linkages, 2002). ASI mengandung zat kekebalan karena terdapat vitamin C dan zat antiperadangan sehingga dapat mencegah bayi mengalami infeksi, baik disebabkan oleh jamur, virus, bakteri, atau parasit. Kandungan SIgA (antibodi yang hanya terdapat dalam ASI) dalam kolostrum hari pertama adalah $800 \mathrm{gr} / 100 \mathrm{cc}$. selanjutnya, mulai berkurang menjadi $600 \mathrm{gr} / 100 \mathrm{cc}$ pada hari kedua, $400 \mathrm{gr} / 100 \mathrm{cc}$ pada hari ketiga, dan $200 \mathrm{gr} / 100 \mathrm{cc}$ pada hari keempat. 
Pada aspek kejiwaan mengacu pada pentingnya memberikan ASI eksklusif pada bayi baru lahir sampai 6 bulan dan terus memberikan ASI sampai anak berusia 24 bulan, karena telah terbukti secara kuat berdampak positif bagi masa depan anak. Penelitian membuktikan bahwa bayi yang diberi ASI eksklusif, menunjukkan perkembangan sosial dan kognitif yang lebih baik dari bayi yang diberi susu formula (Aritonang, 2012). ASI memiliki manfaat yang begitu besar namun sangat disayangkan masih sedikit ibu yang mau atau memberikan ASI eksklusif selama 6 bulan seperti yang disarankan WHO. Berdasarkan data yang dikeluarkan UNICEF di Negara berkembang hanya $38 \%$ bayi berusia 6 bulan yang diberikan ASI eksklusif. Secara nasional cakupan pemberian ASI eksklusif di Indonesia berfluktuasi dan menunjukkan kecenderungan menurun.

Cakupan ASI eksklusif yang rendah terjadi hampir di seluruh wilayah pedesaan maupun perkotaan. Berdasarkan hasil survey yang dilakukan oleh Nutrition \& Health Surveillance System (NSS) dengan Balitbangkes dan Helen Keller International di 4 perkotaan (Jakarta, Surabaya, Semarang, Makasar) dan 8 pedesaan (Sumbar, Lampung, Banten, Jabar, Jatim, NTB, Sulsel) menunjukan bahwa pencapaian ASI eksklusif di pedesaan 2\%-13\%, sedangkan diperkotaan berkisar antara 1\%-13\% (Rahayu, 2008).

Ibu tidak memberikan ASI eksklusif disebabkan oleh beberapa alasan, antara lain pengetahuan ibu tentang pentingnya ASI masih rendah, tata laksana rumah sakit yang salah, dan banyaknya ibu yang mempunyai pekerjaan diluar rumah (Yuliarti, 2010). Pada penelitian Elmiyasna (2009) yang merupakan penyebab rendahnya pemberian ASI Eksklusif adalah rendahnya pengetahuan ibu tentang ASI Eksklusif, masalah dalam ASI seperti ASI tidak keluar. Dukungan keluarga juga diperlukan dalam pemberian ASI, ayah dapat berperan secara langsung dalam mengambil sikap guna membantu ibu untuk memperlancar ASI-nya, seperti membelikan ibu makanan dan vitamin yang dapat memperlancar ASI. Dengan hal-hal kecil yang dilakukan inilah ibu pun bersemangat untuk memberikan ASI eksklusif (Sartika, et al., 2014). Laktasi merupakan keseluruhan proses menyusui, mulai dari ASI diproduksi sampai proses bayi menghisap dan menelan ASI (Prasetyono, 2009). Manajemen laktasi dimulai pada masa kehamilan, setelah persalinan dan masa menyusui bayi. Ruang lingkup manajemen laktasi periode post natal meliputi ASI esklusif, cara menyusui, memeras ASI peras, dan memberikan ASI peras (Siregar, 2009). Bila manajemen laktasi tidak terlaksana maka akan berdampak penurunan pemberian ASI sehingga bisa berdampak pada peningkatan angka gizi buruk dan gizi kurang yang beresiko pada peningkatan kematian bayi (Prasetyono, 2009). Berarti, penting sekali bagi lbu untuk mengetahui tentang manajemen laktasi dengan baik dan benar. Oleh sebab itu, penulis membatasi penelitian yang berkaitan dengan pengaruh pengetahuan ibu tentang manajemen laktasi dengan perilaku dalam pemberian ASI eksklusif.

\section{METODOLOGI PENELITIAN}

Metode penelitian yang digunakan dalam penelitian ini adalah penelitian kuantitatif. Penelitian ini menggunakan pendekatan survey. Peneliti menggunakan metode simple random sampling dengan menggunakan rumus Slovin. Sampel yang digunakan dalam penelitian ini merupakan ibu yang memiliki anak berusia 0-6 bulan di 6 Posyandu Kecamatan Jati Kelurahan Pulo Gadung Jakarta Timur. Setelah melalui proses analisis, hasil yang diperoleh akan diinterpretasi untuk memperoleh kesimpulan dari penelitian. Di dalam penelitian ini diperoleh melalui penggunaan instrument yang berbentuk kuesioner atau angket.

Perilaku pemberian ASI eksklusif diukur menggunakan kuesioner dengan jumlah 20 item soal berbentuk skala likert dengan 4 pilihan jawaban (tidak pernah $=1$; Jarang $=2$; Sering $=3$; Selalu $=4$ ). Untuk mengukur pengetahuan ibu tentang manajemen laktasi menggunakan kuesioner dengan jumlah 35 item soal berbentuk skala guttman dengan pilihan jawaban (benar $=1$; salah $=0$ ). Proses analisis data dilakukan dengan menggunakan aplikasi Microsoft Excel.

\section{HASIL DAN PEMBAHASAN}

Responden dalam penelitian ini adalah ibu yang memiliki anak berusia 0-6 bulan di 6 Posyandu Kecamatan Jati Kelurahan Pulo Gadung Jakarta Timur. Jumlah responden yang terlinat dalam penelitian ini sebanyak 57 ibu. Berikut adalah gambaran umum reponden. 
Tabel 1. Sebaran Data Usia Responden

\begin{tabular}{ccccc}
\hline Kategori & $\mathrm{N}$ & Keterangan & Frekuensi & Presentase \\
\hline \multirow{2}{*}{ Usia } & \multirow{2}{*}{57} & $20-25$ & 25 & $43,86 \%$ \\
& & $26-30$ & 32 & $56,14 \%$ \\
\hline
\end{tabular}

Berdasarkan Tabel 1. dapat dilihat bahwa usia responden antara 20 sampai 25 tahun sebanyak 25 orang $(43,86 \%)$, sedangkan usia responden antara 26 sampai 30 tahun sebanyak 32 orang $(56,14 \%)$. Umur 20-35 tahun merupakan usia yang ideal untuk memproduksi ASI yang optimal dan kematangan jasmani dan rohani dalam diri ibu sudah terbentuk. Umur lebih dari 35 tahun organ reproduksi sudah lemah dan tidak optimal dalam pemberian ASI eksklusif (Hidajati, 2012).

Tabel 2. Sebaran Data Pendidikan Responden

\begin{tabular}{ccccc}
\hline Kategori & $\mathrm{N}$ & Keterangan & Frekuensi & Presentase \\
\hline \multirow{4}{*}{ Tingkat Pendidikan } & & SMP & 5 & $8,8 \%$ \\
& \multirow{2}{*}{57} & SMA & 38 & $66,7 \%$ \\
& & Diploma & 2 & $3,5 \%$ \\
& Sarjana & 12 & $21 \%$ \\
\hline
\end{tabular}

Persentase responden yang memiliki tingkat pendidikan SMP sebanyak $8,8 \%$, tingkat pendidikan SMA 66,7\%, tingkat pendidikan Diploma 3,5\%, dan tingkat pendidikan Sarjana 21\%. Pendidikan orang tua atau keluarga terutama ibu bayi merupakan salah satu faktor yang penting dalam pemberian ASI Eksklusif pada bayi. Tingkat pendidikan yang rendah akan sulit menerima arahan dalam pemberian ASI eksklusif. Tingkat pendidikan yang baik akan lebih mudah dalam menyerap informasi terutama tentang pemenuhan kebutuhan nutrisi anak sehingga akan menjamin kecukupan gizi anak.

Tabel 3. Sebaran Data Pekerjaan Responden

\begin{tabular}{ccccc}
\hline Kategori & $\mathrm{N}$ & Keterangan & Frekuensi & Presentase \\
\hline \multirow{3}{*}{ Pekerjaan Ibu } & \multirow{2}{*}{57} & Ibu Rumah Tangga & 43 & $75,4 \%$ \\
& Karyawan Swasta & 1 & $1,8 \%$ \\
& PNS & 6 & $10,5 \%$ \\
& & Wirausaha & 7 & $12,3 \%$ \\
\hline
\end{tabular}

Persentase responden lbu Rumah Tangga sebanyak 75,4\%, pekerjaan Karyawan Swasta sebanyak 1,8\%, pekerjaan Pegawai Negeri Sipil sebanyak 10,5\%, pekerjaan Wirausaha sebanyak $12,3 \%$. Ibu yang bekerja akan menghadapi beberapa kendala dalam memberikan ASI eksklusif kepada bayinya, antara lain:waktu, kualitas kebersamaan dengan bayi, beban kerja, stress, dan keyakinan ibu untuk memberikan ASI eksklusif akan terpengaruh. Ibu yang bekerja memiliki keyakinan yang rendah untuk memberikan ASI eksklusif (Notoadmodjo, 2010).

Dalam penelitian ini terdapat dua variabel, yaitu pengetahuan manajemen laktasi dan perilaku pemberian ASI eksklusif. Pada variabel pengetahuan manajemen laktasi didapatkan data seperti tabel berikut:

Tabel 4. Distribusi Frekuensi Pengetahuan Ibu Tentang Manajemen Laktasi

\begin{tabular}{|c|c|c|c|c|c|}
\hline \multicolumn{2}{|c|}{ Kelas Interval } & \multirow{2}{*}{$\begin{array}{c}\text { Batas Bawah } \\
15.5\end{array}$} & \multirow{2}{*}{$\begin{array}{c}\text { Batas Atas } \\
18.5\end{array}$} & \multirow{2}{*}{$\begin{array}{c}\text { Frek. Absolut } \\
2\end{array}$} & \multirow{2}{*}{$\begin{array}{c}\text { Frek. Relatif } \\
3.5 \%\end{array}$} \\
\hline 16 & 18 & & & & \\
\hline 19 & -21 & 18.5 & 21.5 & 3 & $5.3 \%$ \\
\hline 22 & 24 & 21.5 & 24.5 & 5 & $8.8 \%$ \\
\hline 25 & 27 & 24.5 & 27.5 & 8 & $14.0 \%$ \\
\hline 28 & -30 & 27.5 & 30.5 & 14 & $24.6 \%$ \\
\hline 31 & $-\quad 33$ & 30.5 & 33.5 & 15 & $26.3 \%$ \\
\hline 34 & $-\quad 36$ & 33.5 & 36.5 & 10 & $17.5 \%$ \\
\hline & & Jumlah & & 57 & $100 \%$ \\
\hline
\end{tabular}


Berdasarkan tabel distribusi frekuensi pada variabel pengetahuan tentang manajemen laktasi di atas dapat diketahui banyaknya kelas interval sebesar 7 kelas. Frekuensi relatif terbesar berada pada kelas 6 yaitu dengan rentang 31-33 dengan persentase 26,3\% dengan jumlah responden sebanyak 15. Sementara itu frekuensi rendah pada kelas 1 dengan rentang 16-18 sebanyak 2 responden dengan persentase $3,5 \%$. Maka dengan itu dari proses penghitungan pada tiap dimensi dan indikator ditetapkan hasil rata-rata hitung skor pada masing-masing dimensi dan indikator tersebut.

Dari proses penghitungan pada setiap dimensi dan indikator ditetapkan hasil rata - rata hitung skor pada masing - masing dimensi dan indikator dari variabel pengetahuan manajemen laktasi yang menyatakan persentase pengaruh dimensi tersebut.

Dimensi dari pengetahuan manajemen laktasi yang pertama adalah dimensi masa kehamilan didapat presentase sebesar $34,78 \%$ dengan jumlah rata-rata WMS sebesar 0,86 dan termasuk kategori sangat tinggi. Pada indikator pentingnya ASI untuk bayi didapatkan presentase sebesar $9,3 \%$ dengan jumlah rata-rata WMS sebesar 0,84 dengan kategori pilihan jawaban benar. Indikator cara meningkatkan produksi ASI selama kehamilan mendapat presentase $9,49 \%$ dengan jumlah rata-rata WMS 0,86 dengan kategori pilihan jawaban benar. Indikator cara memperlancar saluran air susu $10,66 \%$ dengan jumlah rata-rata WMS 0,95 dengan kategori pilihan jawaban benar. Dapat dilihat dari gambar diagram dimensi masa kehamilan dibawah ini:

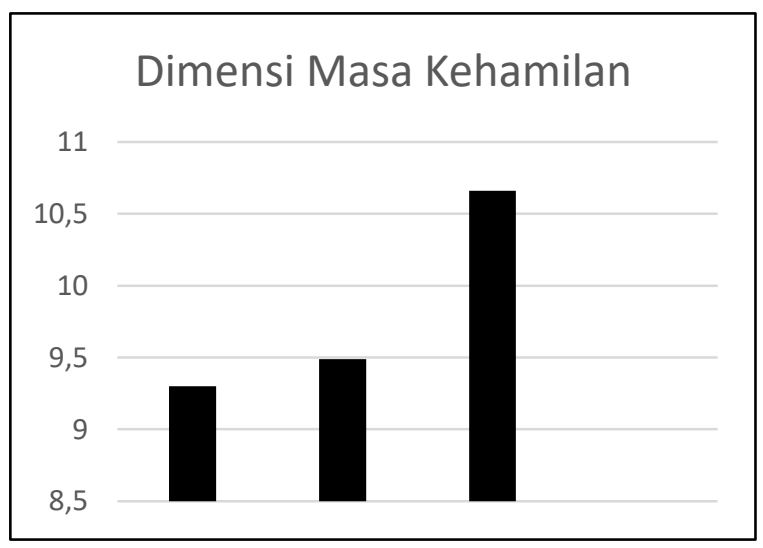

Gambar 1. Grafik Dimensi Masa Kehamilan

Dimensi dari pengetahuan manajemen laktasi yang kedua adalah pasca persalinan didapat presentase sebesar $33,52 \%$ dengan jumlah rata-rata WMS sebesar 0,83 dan termasuk kategori sangat tinggi. Pada indikator mengetahui definisi IMD didapatkan presentase sebesar 10,17\% dengan jumlah rata-rata WMS sebesar 0,92 dengan kategori pilihan jawaban benar.Indikator mengetahui pentingnya melakukan IMD 9,49\% dengan jumlah rata-rata WMS sebesar 0,86 dengan kategori pilihan jawaban benar. Indikator cara menyusui pada saat IMD $8,52 \%$ dengan jumlah rata-rata WMS sebesar 0,77 dengan kategori pilihan jawaban benar. Dapat dilihat gambar diagram dimensi pasca persalinan dibawah ini :

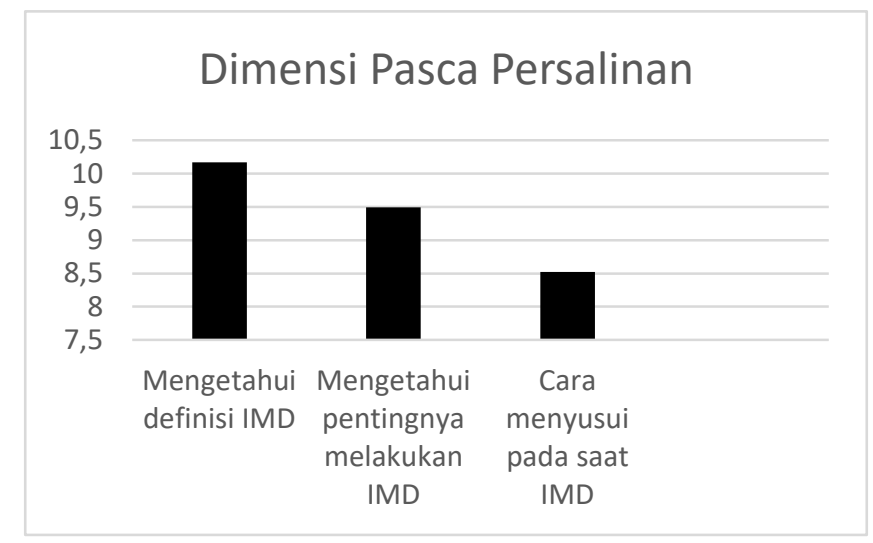

Gambar 2. Grafik Dimensi Pasca Persalinan 
Dimensi dari pengetahuan manajemen laktasi yang ketiga adalah masa menyusui memiliki presentase sebesar $31,71 \%$ dengan jumlah rata-rata WMS sebesar 0,79 dan termasuk kategori tinggi. Pada indikator mengetahui definisi ASI Eksklusif didapatkan presentase sebesar 9,75\% dengan jumlah rata-rata WMS sebesar 0,88 dengan kategori pilihan jawaban benar. Indikator manfaat ASI Eksklusif 8,91\% dengan jumlah rata-rata WMS sebesar 0,81 dengan kategori pilihan jawaban benar. Indikator proses produksi ASI 6,78\% dengan jumlah rata-rata WMS sebesar 0,61 dengan kategori pilihan jawaban benar. Indikator cara menyusui yang benar $8,01 \%$ dengan jumlah rata-rata WMS sebesar 0,73 dengan kategori pilihan jawaban benar. Indikator waktu pemberian ASI 8,91\% dengan jumlah rata-rata WMS sebesar 0,81 dengan kategori pilihan jawaban benar. Indikator cara meningkatkan produksi ASI pada masa menyusui 8,43\% dengan jumlah rata-rata WMS sebesar 0,76 dengan kategori pilihan jawaban benar. Dapat dilihat gambar diagram dimensi masa menyusui dibawah ini:

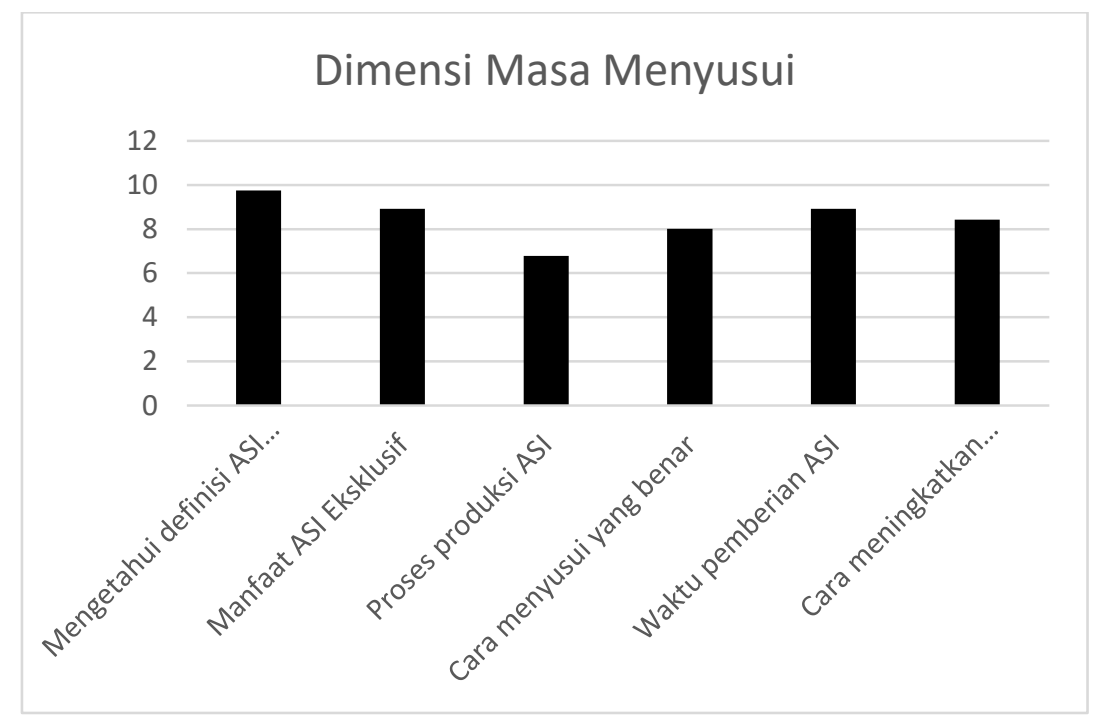

Gambar 5. Dimensi Masa Menyusui

Data variabel perilaku pemberian ASI eksklusif dapat dilihat pada tabel berikut:

Tabel 5. Distribusi Frekuensi Variabel Perilaku Pemberian ASI eksklusif

\begin{tabular}{|c|c|c|c|c|c|c|}
\hline \multicolumn{3}{|c|}{ Kelas Interval } & $\begin{array}{c}\text { Batas } \\
\text { Bawah }\end{array}$ & $\begin{array}{c}\text { Batas } \\
\text { Atas }\end{array}$ & $\begin{array}{l}\text { Frek. } \\
\text { Absolut }\end{array}$ & Frek. Relatif \\
\hline 41 & - & 46 & 40.5 & 46.5 & 4 & $7.0 \%$ \\
\hline 47 & - & 52 & 46.5 & 52.5 & 6 & $10.5 \%$ \\
\hline 53 & - & 58 & 52.5 & 58.5 & 8 & $14.0 \%$ \\
\hline 59 & - & 64 & 58.5 & 64.5 & 12 & $21.1 \%$ \\
\hline 65 & - & 70 & 64.5 & 70.5 & 13 & $22.8 \%$ \\
\hline 71 & - & 76 & 70.5 & 76.5 & 11 & $19.3 \%$ \\
\hline 77 & - & 82 & 76.5 & 82.5 & 3 & $5.3 \%$ \\
\hline \multicolumn{5}{|c|}{ Jumlah } & 57 & $100 \%$ \\
\hline
\end{tabular}

Berdasarkan tabel distribusi frekuensi ada variabel perilaku pemberian ASI eksklusif di atas dapat diketahui banyaknya kelas interval sebesar 7 kelas. Frekuensi relatif tebesar berada pada kelas 5 yaitu dengan rentang $65-70$ dengan presentase $22,8 \%$ sementara itu frekuensi rendah berada pada kelas 7 dengan rentang $77-82$ dengan presentase 5,3\%.

Melalui penghitungan dari setiap dimensi dan indikator didapatkan hasil rata-rata hitungan skor pada masing-masing dimensi, indikator, dan variabel perilaku pemberian ASI Eksklusif yang 
menyatakan presentase hubungan dimensi serta indikator tersebut. Berikut adalah pembahasan presentase dari jumlah alternative jawaban yang dipilih para responden.

Dimensi dari perilaku pemberian ASI Eksklusif yang pertama adalah Inisiasi Menyusui Dini memiliki presentase sebesar 50,20\% dengan jumlah rata - rata WMS sebesar 3,16 dan termasuk kategori baik. Pada indikator melakukan IMD setelah bayi lahir didapatkan presentase sebesar 16,62\% dengan jumlah rata - rata WMS sebesar 3,14 dengan kategori pilihan jawaban setuju, dan dari indikator melakukan rawat gabung 24 jam setelah melahirkan 16,97\% dengan jumlah rata - rata WMS sebesar 3,2 dengan kategori pilihan jawaban setuju. . Dapat dilihat gambar grafik dimensi Inisiasi Menyusui Dini dibawah ini :

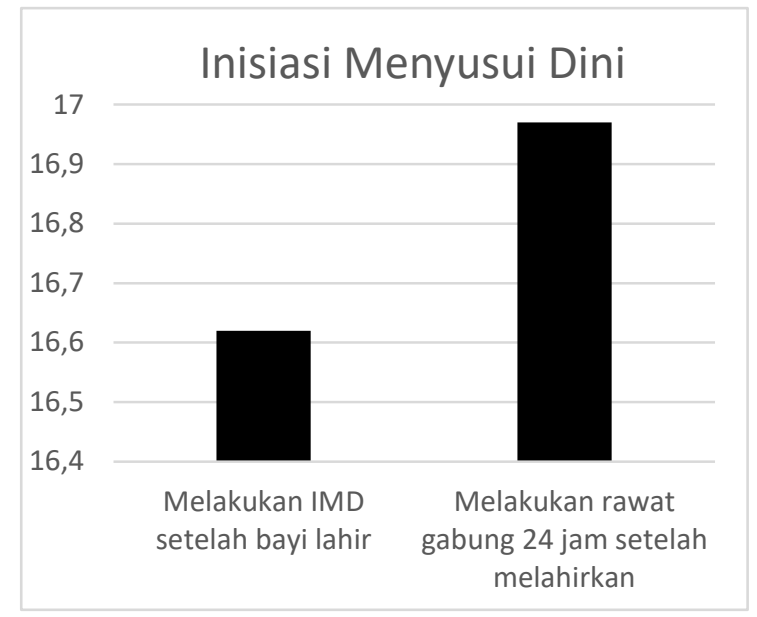

Gambar 6. Grafik Dimensi Inisiasi Menyusui Dini

Dimensi dari perilaku pemberian ASI Eksklusif yang kedua adalah ASI Eksklusif didapatkan presentase sebesar $49,80 \%$ dengan jumlah rata - rata WMS sebesar 3,13 dan termasuk kategori tinggi. Pada indikator memberikan ASI tanpa tambahan apapun selama bayi 0-6 didapatkan presentase sebesar 16,05\% dengan jumlah rata - rata WMS sebesar 3,03 dengan kategori pilihan jawaban setuju. Indikator kendala dalam pemberian ASI Eksklusif 15,99\% dengan jumlah rata - rata WMS sebesar 3,02 dengan kategori pilihan jawaban setuju. Indikator meningkatkan produksi ASI $17,14 \%$ dengan jumlah rata - rata WMS sebesar 2,56 dengan kategori pilihan jawaban setuju. Indikator mempertahankan produksi ASI 17,22\% dengan jumlah rata - rata WMS sebesar 2,57 dengan kategori pilihan jawaban setuju. Dapat dilihat gambar diagram dimensi ASI Eksklusif dibawah ini:

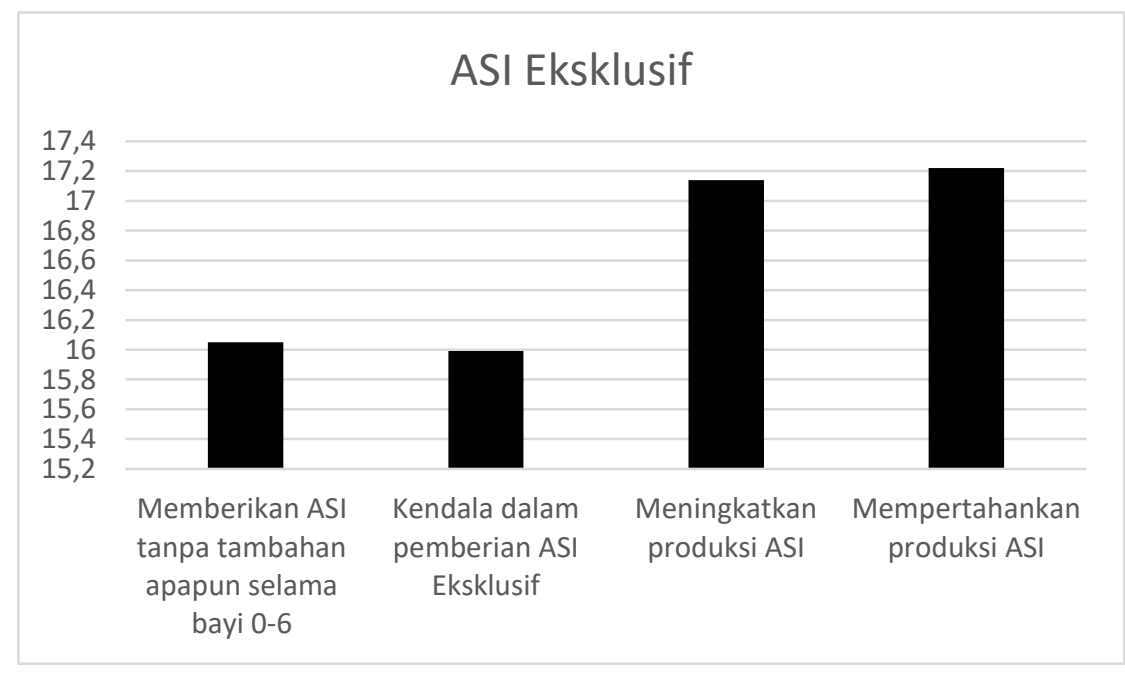

Gambar 7. Grafik Dimensi ASI Eksklusif 
Hasil penelitian menggambarkan bahwa nilai koefisien korelasi $r_{\text {hitung }} 0,627$ dan $t_{\text {hitung }}=5,97$ lebih besar dari $t_{\text {tabel }}=2,004$. Hasil uji persamaan regresi adalah sebesar 23,54 menunjukkan bahwa apabila terdapat variabel pengetahuan tentang manajemen laktasi dengan perilaku pemberian ASI Eksklusif, maka perilaku pemberian ASI Eksklusif sebesar 53,48. Nilai parameter atau koefisien arah regresi positif sebesar 1,357 yang berarti setiap kenaikan pengetahuan tentang manajemen laktasi sebesar 1 satuan dengan konstanta 23,54 maka akan menaikkan pengetahuan tentang manajemen laktasi sebesar 1,357. Kemudian signifikansi regresi didapatkan $F_{\text {hitung }}=35,58$ dan $F_{\text {tabel }}=4,02$ yang berarti bahwa pengaruh pengetahuan tentang manajemen laktasi terhadap perilaku pemberian ASI eksklusif terjadi secara signifikan di posyandu Kelurahan Jati, Jakarta Timur. Pengaruh yang signifikan ini diungkapkan oleh Notoadmodjo (2005) bahwa perilaku yang didasari oleh pengetahuan akan lebih langgeng dari pada perilaku yang tidak didasari dengan pengetahuan. Besarnya sumbangan pengetahuan manajemen laktasi terhadap perilaku pemberian ASI Eksklusif adalah 39,28 sehingga semakin baik pengetahuan .manajemen laktasi maka semakin baik pula perilaku pemberian ASI Eksklusif dan sebaliknya. Hasil penelitian menunjukkan adanya kecenderungan responden yang memiliki pengetahuan manajemen laktasi tinggi akan mempunyai perilaku baik dalam pemberian ASI eksklusif, dan responden yang memiliki pengetahuan kurang akan mempunyai perilaku cukup dalam pemberian ASI eksklusif.

\section{KESIMPULAN}

Pengetahuan manajemen laktasi terbukti mempengaruhi perilaku pemberian ASI eksklusif secara signifikan pada ibu di 6 Posyandu Kecamatan Jati Kelurahan Pulo Gadung Jakarta Timur. Pengetahuan manajemen laktasi memiliki peran sebesar 39,28\% dalam membentuk perilaku pemberian ASI eksklusif. Sedangkan 60,72\% lainnya dibentuk oleh faktor lain. Persamaan regresi pada penelitian ini adalah $\hat{Y}=23,54+1,357 \mathrm{X}$, artinya setiap kenaikan satu unit skor pengetahuan manajemen laktasi maka akan meningkatkan 1,357 skor perilaku pemberian ASI esklusif. Terdapat pengaruh positif signifikan antara Pengetahuan Tentang Manajemen Laktasi Terhadap Perilaku Pemberian ASI Eksklusif, sehingga Pengetahuan Tentang Manajemen Laktasi yang didapat dari posyandu dan fasilitas kesehatan lainnya menjadi salah satu solusi alternatif dalam menerapkan perilaku pemberian ASI Eksklusif yang baik dan benar.

\section{DAFTAR PUSTAKA}

Aritonang, I., 2012. Penyelenggaraan Makanan. Yogyakarta: s.n.

Depkes, R., 2003. Indikator Indonesia Sehat 2010 dan Pedoman Penetapan Indikator Provinsi Sehat dan Kabupaten/Kota Sehat. Jakarta: s.n.

Hesti, W., 2013. Cara Mengelola ASI eksklusif Bagi lbu Bekerja. Yogyakarta: Gosyen Publishing. Hidajati, A., 2012. Mengapa Ibu Harus Menyusui?. Yogyakarta: Flashbooks.

Hien Nguyen Ngoc \& Kam Sin, 2008. Nutritional Status and the Characteristics Related to Malnutrition in Children Under Five Years of Age in Nghean, Vietnam. Vietnam: J Prev Med Public Health.

Linkages, 2002. Pemberian ASI eksklusif atau ASI saja. Satu-satunya Sumber Cairan yang Dibutuhkan Bayi Usia Dini, diakses pada tanggal 1 Mei dari www.linkagesproject.org

Notoadmodjo, 2010. Metodologi Penelitian Kesehatan. Jakarta: Rineka Cipta.

Prasetyono, 2009. Buku Pintar ASI eksklusif. Yogyakarta: Diva Press.

Rahayu, S., 2008. Keperawatan Keluarga. Yogyakarta: Graha IImu.

Sartika, Istiani, A. \& Riska, N., 2014. Gambaran Pengetahuan dan Sikap Ayah tentang Pemberian ASI Eksklusif. Jurnal Kesejahteraan Keluarga dan Pendidikan. Vol.1, p. 59.

Siregar, A., 2009. Pemberian ASI Eksklusif dan Faktor-Faktor yang Mempengaruhinya. Sumatera Utara: s.n.

WHO, 2014. Commission on Ending Childhood Obesity. Geneva: s.n.

Yuliarti, 2010. Keajaiban ASI: Makanan Terbaik untuk Kesehatan, Kecerdasan dan Kelincahan si Kecil. Yogyakarta: Andi Publisher. 